\title{
SERRATIA MARCESCENS BACTEREMIA ASSOCIATED WITH SCHISTOSOMIASIS MANSONI
}

\author{
Sérgio de Andrade Nishioka, Marcelo Simão Ferreira and Marcius Kleber \\ Nunes Burgarelli
}

\begin{abstract}
The case of a 21-year-old man coming from rural Paraiba, northeastern Brazil, with schistosomiasis mansoni associated with Serratia marcescens bacteremia, is reported. His main complaints on admission were fever, diaphoresis and chills for ten days, and diarrhoea that lasted for four days. On physical examination he had jaundice and hepatosplenomegaly. Diagn sis of $\mathrm{S}$. marcescens bacteremia was made by isolation of the bacterium in blood culture, and schistosomiasis was diagnosed by rectal and liver biopsies. This is the first time that the association of S. marcescens bacteremia and schistosomiasis mansoni is recognized. Although our case does not fit into the classic definition of prolonged bacteremia associated with schistosomiasis, it can be considered as a mild form of this association. With the improvement of medical assistance and laboratory facilities, early diagnosis of this association will be made more frequently, cases with short duration will be diagnosed few days after the start of the symptoms, and classic prolonged cases will become rarer.
\end{abstract}

Key-words: Bacteremia. Schistosoma mansoni. Schistosomiasis mansoni. Serratia marcescens.

Schistosomiasis mansoni is an important parasitic disease in the developing world. In Brazil, where recent figures are not available, there was an estimated prevalence of 8 million people with the disease in $1972^{2}$.

Although most people have mild forms of the disease, among those with the hepatosplenic form many die from a cause directly related to their disease, mainly haemorrhage from ruptured oesophageal varices. Patients with the hepatosplenic form of the disease have also a higher risk of having chronic hepatitis $B^{3}$ and lymphoma of the spleen $^{1}$ than the normal population.

Since the 1950s it has been recognized that some patients with hepatosplenic schistosomiasis have prolonged bacteremia by Salmonella species, including Salmonella typhi ${ }^{5}$. Prolonged bacteremia by other Enterobacteriacea has been recognized less frequently.

We herein report the case of a patient with

\footnotetext{
Centro de Ciências Biomédicas, Universidade Federal de Uberlândia, Uberlândia, MG, Brasil.

Address to: Dr. Sérgio de Andrade Nishioka. Centro de Ciências Biomédicas/UFU. Av. Pará 1720, 38400-902 Uberlândia, MG, Brasil.

Recebido para publicaçāo em 15/09/92.
}

schistosomiasis mansoni and Serratia marcescens bacteremia.

\section{CASE REPORT}

A 21-year-old male, coming from rural Paraíba state, northeastern Brazil, was admitted to the hospital complaining of fever $\left(38.5-39^{\circ} \mathrm{C}\right)$ for 10 days, one to three times per day, with diaphoresis and chills. He complained also of diarrhoea that lasted for four days. He denied previous hospitalization.

On physical examination, his temperature was $39^{\circ} \mathrm{C}$, pulse 68 , and respirations 20 . The blood pressure was $110 / 60 \mathrm{mmHg}$. He appeared well and had, as positive findings, scleral jaundice, the liver $5 \mathrm{~cm}$ below the right costal margin, and the spleen $3 \mathrm{~cm}$ below the left costal margin. No rash or lymphadenopathy was found.

The haematocrit was $42.3 \%$, haemoglobin $13.9 \mathrm{~g} \%$, leucocytes 9600 ( $1 \%$ metamyelocytes, $19 \%$ band forms, $63 \%$ neutrophils, $16 \%$ lymphocytes, $1 \%$ monocytes), platelets $199000 / \mathrm{mm}^{3}$. Bilirubins were $4.06 \mathrm{mg} \%$, alanine aminotransferase $132 \mathrm{IU} / 1$, alkaline phophatase $1299 \mathrm{IU} / \mathrm{l}$. The urea nitrogen, creatinine, glycemia, amylase and electrolytes were normal. 
Relato de Caso. Nishioka SA, Ferreira MS, Burgarelli MKN. Serratia marcescens bacteremia associated with schistosomiasis mansoni. Revista da Sociedade Brasileira de Medicina Tropical 25:191-193, jul-set, 1992.

Ultrasonographic scan of the abdomen showed only bepatosplenomegaly. An echodopplercardiogram was within normal limits.

Several blood cultures were positive for Serratia marcescens, which was sensitive in vitro (KirbyBauer) to all tested antimicrobials (ampicillin, chloramphenicol, cotrimoxazole, gentamicin, tobramycin, amikacin, cefoxitin, ceftriaxone, imipenem and ciprofloxacin). Stool culture was negative.

Repeated stool examinations for ova of parasites were negative. Histological examination of a fragment of rectal mucosa obtained by biopsy revealed structures suggestive of degenerated ova (one calcified) of $S$. mansoni within granulomata. Histological examination of a liver fragment obtained by percutaneous biopsy showed a periportal infiltrate of lymphocytes, plasma cells and some eosinophils, periportal fibrosis, and a granuloma with giant cells type foreign body, surrounded by fibrosis.

The patient was initially treated with intravenous ampicillin for seven days, and with a single oral dose of oxamniquine, with general improvement, but wighout effect on the fever. Tobramycin was then started, and continued for 13 days, although the fever disappeared in two days. At the end the treatment, the spleen was not palpable anymore. Discharge of the hospital was delayed by the development of hospital-acquired chickenpox, from which the patient had an uneventful recovery.

\section{DISCUSSION}

Prolonged bacteremia associated to schistosomiasis has been defined as a chronic infection by Enterobacteriacea in patients with schistosomiasis, clinically characterized by prolonged fever, hepatosplenomegaly, weight loss, anemia, abdominal pain and diarrhoe ${ }^{5}$. Most cases of prolonged bacteremia associated with schistosomiasis have been reported in hepatosplenic patients and by Salmonella species. Other Enterobacteriacea that hav also been associated with bacteremia in patients with schistosomiasis are E. coli, Shigella, Klebsiella, Proteus, Enterobacter and Citrobacter ${ }^{467}$. Serratia marcescens has been diagnosed as the aetiologic agent in all kinds of infection, mostly nosocomial infections ${ }^{8}$, but to our knowledge this is the first time that bacteremia by Serratia associated with schistosomiasis is recognized.

Although Serratia marcescens has been isolated from water, soil, foodstuffs, animals and sewage ${ }^{8}$, it was not clear what was the portal of entry of this organism in this patient. We believe that this was a community-acquired infection, as the patient was admitted already with fever, denied previous hospitalization, was not submitted to intravenous or urinary tract catheterization, and because the strain of Serratia was sensitive in vitro to common antimicrobial agents like ampicillin, chloramphenicol and cotrimoxazole.

The patient had a mild jaundice probably due to cholestatic hepatitis secondary to Gram negative bacteremia, as it disappeared following treatment with antibiotics. Splenomegaly, noticed on admission, also disappeared after the use of antimicrobials, suggesting that the patient had the hepatointestinal form of schistosomiasis, and that the enlargement of the spleen was reactive to the bacteremia.

The patient did not respond to intravenous administration of ampicillin for 7 days, although the isolated strain of Serratia was sensitive in vitro (Kirby Bauer) to it, and he improved only after tobramycin was introduced.

Our case does not fit into the classic definition of prolonged bacteremia associated with schistosomiasis, as most of the patients reported in the initial reports had fever for months. It can be considered as a mild form of this association, as described by Teixeira ${ }^{5}$. It is our view that, with the improvement of medical assistance, and as laboratory facilities become available in endemic areas of schistosomiasis, early diagnosis of the association will be made more frequently. Therefore, most cases will be diagnosed few days after the start of the symptoms, and classic prolonged cases will become rarer.

\section{RESUMO}

O caso de um homem de 21 anos, procedente da zona ruralda Paraiba, estado do nordeste do Brasil, com esquistossomose mansônica associada com bacteremia por Serratia marcescens, é relatado. Suas queixas principais à admissão foram febre, sudorese e calafrios 
Relato de Caso. Nishioka SA, Ferreira MS, Burgarelli MKN. Serratia marcescens bacteremia associated with schistosomiasis mansoni. Revista da Sociedade Brasileira de Medicina Tropical 25:191-193, jul-set, 1992.

por dez dias, e diarréia por quatro dias. Ao exame físico, apresentava ictericia e hepatoesplenomegalia. $O$ diagnóstico da bacteremia foi feito pelo isolamento da bactéria em hemoculturas, e a esquistossomose foi diagnosticada através de biópsias retal e hepática. Esta é a primeira vez que a associação de bacteremia por $\mathbf{S}$. marcescens e esquistossomose mansônica éreconhecida. Embora nosso caso não se en quadre na definição clássica de bacteremia prolongada associada à esquistossomose, ele pode ser considerado como uma forma leve desta associação. Com a melhoria da assistência médica e dos recursos de diagnóstico laboratorial, o reconhecimento precoce da associação será feito mais freqüentemente, $o$ diagnóstico será realizado poucos dias após o início dos sintomas, e casos prolongados tornar-se-ão mais raros.

Palavras-chaves: Bacteremia. Esquistossomose mansônica. Schistosoma mansoni. Serratia marcescens.

\section{REFERENCES}

1. Andrade ZA, Andrade SG. Patologia do baço na esquistossomose hepatoesplênica. Revista do Instituto de Medicina Tropical de São Paulo 7:218-227, 1965.

2. Freitas CA. Situação atual da esquistossomose no Brasil. Revista Brasileira de Malariologia e Doenças Tropicais 24:3-19, 1972.

3. Lyra LG, Rebouças G, Andrade ZA. Hepatitis B surface antigen "carrier" state in hepatosplenic schistosomiasis. Gastroenterology 71:641-645, 1976.

4. Neves J, Lambertucci JR. Salmonelose septicêmica prolongada. In: Neves J (ed) Doenças Infectuosas e Parasitárias. Guanabara Koogan, Rio de Janeiro p.580-591, 1983.

5. Teixeira R. Associação de infecção por S. mansoni com bactérias do gênero Salmonella. In: Centro de Doenças Regionais (ed) Aspectos peculiares da infecção por Schistosoma mansoni, Centro Editorial e Didático da Universidade Federal da Bahia, Salvador p.35-64, 1984.

6. Teixeira R, Bina JC, Oliveira V, Barreto SH. Septicemia prolongada por bactéria Gram negativa do gênero Escherichia em paciente com esquistossomose mansônica. Revista da Sociedade Brasileira de Medicina Tropical 6:411, 1972.

7. Tonelli E. Salmonelose septicêmica prolongada. In: Tonelli E (ed) Doenças Infecciosas na Infância, Editora Medsi, Rio de Janeiro p.409-417, 1987.

8. Yu VL. Serratia marcescens: historical perspective and clinical review. NewEngland Journal of Medicine 300:887-893, 1979. 